30-June 1); Edgar Allen and Co., Ltd., and Had. fields, Ltd., Sheffield (June 21); Brown, Lenox and Co., Ltd., Pontypridd (July 4); English Steel Castings Corporation, Ltd., Sheffield (July 5); Stewarts and Lloyds, Ltd.. Glasgow (September 20); Osborn Foundry and Engineering Co., Ltd., Sheffield (September 21). A conference will also be held in London on May 10. Further information can be obtained from Mr. K. V. Robinson, British Steel Founders' Association, 13 Broomgrove Road, Sheffield 10.

\section{Selby Fellowship}

The Selby fellowship has been established by the Australian Academy of Science to bring graduates of high promise and proved capacity for research to work in the laboratories of universities or research institutions in Australia. The fellowship may be awarded in any branch of physical or biological science and is tenable at any university or research institution in Australia, normally for one full year of work. Candidates must have taken their first university degree, and have had preliminary research experience, at some university or universities in a country other than Australia. In general, they should hold a Ph.D. degree or have equivalent status and experience, but the fellowship will not normally be given to those who have already held a senior research award. Applicants should be less than thirty years of age on July 1 in the year in which their applications are received. The fellowship will carry a stipend of $£ 2,000$ (Australian) per annum. The costs of the Fellow's travel to Australia, and back to his country of origin at the conclusion of the fellowship, will be provided, up to a limit of $£ A 500$, including dependants, if any. Applications should be sent to the Assistant Secretary, Australian Academy of Science, Gordon Street, Canberra City, A.C.T., before July 30 .

\section{The Night Sky in May}

New moon occurs on May 4d. 04h. 25m. U.T. and full moon on May 19d. 14h. 32m. The following conjunctions with the Moon take place: May ld. 19h., Mars $3^{\circ}$ N.; May 6d. 00h., Aldebaran $1^{\circ}$ S.; May 12d. 06h., Regulus $1^{\circ}$ S.; May 25d. 03h., Saturn $0 \cdot 6^{\circ}$ S.; May 27d. 04h., Jupiter $2^{\circ}$ N.; May 30d. $15 \mathrm{~h}$., Mars $4^{\circ} \mathrm{N}$. In addition to these conjunctions with the Moon, Venus is in conjunction with Aldebaran on May 6d. 18h., Venus being $6^{\circ} \mathrm{N}$., and Mercury with Aldebaran on May 10d. 10h., Mercury being $8^{\circ} \mathrm{N}$. Mercury is well placed for observation during the first three weeks of May, when it is visible low in the west after sunset, setting about $2 \mathrm{hr}$. after the Sun. Venus is an evening star, visible in the west after sunset. It sets at $21 \mathrm{~h} .35 \mathrm{~m} ., 22 \mathrm{~h}$. $15 \mathrm{~m}$. and $22 \mathrm{~h} .40 \mathrm{~m}$. on May 1,15 and 31 , respectively; its stellar magnitude is $-3 \cdot 3$. Its distance decreases during the month from 142 to 127 million miles and the visible portion of the apparent disk decreases from 0.918 to 0.847 . Mars is too close to the Sun for observation. Jupiter rises at $2 \mathrm{~h}$. $50 \mathrm{~m}$., $1 \mathrm{~h} .50 \mathrm{~m}$. and $0 \mathrm{~h} .55 \mathrm{~m}$, at the beginning, middle and end of the month, respectively. It is in Aquarius, its stellar magnitude is $-\mathbf{1 . 9}$ and its distance from the Earth in the middle of the month is 480 million miles. Saturn is in Capricornus, rising at $1 \mathrm{~h} .50 \mathrm{~m}$., $0 \mathrm{~h} .55 \mathrm{~m}$. and $23 \mathrm{~h} .55 \mathrm{~m}$. on May 1,15 and 31 , respectively. Its stellar magnitude is +0.8 and its distance from the Earth on May 15 is 900 million miles. There are no occultations of stars brighter than magnitude 6 visible at Greenwich. Comet Seki-Lines (1962c) will have faded to magnitude 8 by early May, and to magnitude 11 by the end of May.

\section{Announcements}

Sir Harold Jeffreys, formerly Plumian professor of astronomy in the University of Cambridge, and Fellow of St. John's College, Cambridge, has been granted the Grove Karl Gilbert Award in Seismic Geology by the Carnegie Institution of Washington to carry out a programme of correcting his long standard "Travel-time tables".

Mr. F. P. Doyle has been elected to the Board of Directors of the Beecham Research Laboratories, Ltd., as research director. Mr. Doyle succeeds Dr. $J$. Farquharson, who relinquishes his post on medical advice. Dr. Farquharson will later take up an appointment as special consultant directly responsible to the research director, Beecham Group, Ltd.

THe annual general meeting of the American Philosophical Society will be held in Philadelphia during April 26-28. Further information can be obtained from the Secretary, American Philosophical Society, 104 South Fifth Street, Philadelphia.

AN international conference on "Instrumentation for High Energy Physics", sponsored by the International Union of Pure and Applied Physies, will be held at CERN, Geneva, during July 16-18. Further information can be obtained from Mr. E. W. D. Steel. Scientific Conference Secretariat, CERN, Geneva 23.

A sPECIAL meeting, arranged by the Iron and Steel Institute, will be held in Germany during June 27 July 11. The main meeting will be held in Düsseldorf during July 1 -8, and there will be special excursions to Saarland and Trier, to Heidelberg and Frankfurt Main, and to Salzgitter and Bremen. Further information can be obtained from the Secretary, the Iron and Steel Institute, 4 Grosvenor Gardens. London, S.W.1.

ThF Industrial Safoty Division of the Royal Society for the Prevention of Accidents is organizing a conference with the theme "Safety by Research", which will be hold in Blackpool during Mav 10-13. The programme will include: publicizing the results of safety research; safety at work: the trade union point of view; a new jook at accident prevention and its implication for practice; the development and influence of British standards on safety. There will also be an exhibition of industrial safety equipment. Further information can be obtained from the Royal Society for the Prevention of Accidents. Industrial Safety Division, Terminal House, 52 Grosvenor Gardens, London, S.W.1.

A SYMPosIum on "Electromagnetic Theory and Antennas", sponsored by the International Scientific Radio Union, the Technical University of Denmark, the Danish Academy of Technical Sciences and the Danish National Committee of the International Scientific Radio Union, will be hold in the Technical University of Denmark, Copenhagen, during June 25-30. The programme will include the following topics: propagation of guided and unguided electromagnetic waves in anisotropic media; scattering in random media; propagation along and radiation from modulated structures; properties of partially coherent electromagnetic fields; recent developments in diffraction theory; antennas. Further information can be obtained from the secretary of the symposium. H. Lottrup Knudsen. Oster Voldgade $10 \mathrm{G}$, Copen. hagen $\mathrm{K}$. 